\title{
Multidrug Resistant Tuberculosis (MDR-TB): Tinjauan Epidemiologi dan Faktor Risiko Efek Samping Obat Anti Tuberkulosis
}

\author{
Reviono, ${ }^{1}$ P. Kusnanto, ${ }^{2}$ Vicky Eko, ${ }^{3}$ Helena Pakiding, ${ }^{1}$ Dyah Nurwidiasih ${ }^{1}$ \\ ${ }^{1}$ Bagian Pulmonologi dan Ilmu Kedokteran Respirasi, ${ }^{2}$ Bagian Penyakit Dalam Sub Bagian \\ Gastrohepatologi, ${ }^{3}$ Bagian Telinga Hidung Tenggorokan-Kepala Leher Fakultas Kedokteran \\ Universitas Sebelas Maret Surakarta/Rumah Sakit Dr. Moewardi
}

\begin{abstract}
Abstrak
Kasus multi drug resistant tuberculosis (MDR TB) terus meningkat. Penatalaksanaan klinis MDR TB lebih rumit dibandingkan dengan TB sensitif karena menggunakan obat anti-TB lini I dan lini II, sehingga menyebabkan permasalahan toleransi dan efek samping. Desain penelitian ini kohort yang bertujuan untuk mengetahui jenis, frekuensi, dan faktor risiko efek samping obat. Pelaksanaan penelitian dilakukan antara Januari 2011-Juni 2013. Suspek MDR TB diambil sputum, dilakukan pengecatan Ziehl Nielsen, dilanjutkan pemeriksaan Xpert MTB/ RIF pada regio gen $r р о B$ untuk menentukan resistensi rifampisin. Selanjutnya uji resistensi obat anti-TB dengan menggunakan media padat (Lowenstein Jensen) dan media cair Mycobacteria growth indicator tube test (MGIT). Penelitian dilakukan di RS Dr. Moewardi. Jumlah pasien yang terkonfirmasi MDR TB adalah 114 orang: 56 lakilaki dan 58 perempuan. Efek samping terbanyak gangguan gastrointestinal: mual 79,8\%, muntah 78,9\%. Sebagian besar efek samping derajat ringan 76,3\%. Terdapat hubungan antara riwayat pengobatan TB dan gangguan renal $(p=0,026)$, antara jenis kelamin dan gangguan renal $(p=0,033)$ serta gangguan pendengaran $(p=0,039)$. Tidak terdapat hubungan antara jenis kelamin dan gangguan psikiatri $(p=0,062)$, antara riwayat pengobatan TB dan gangguan pendengaran $(p=0,115)$ serta hipokalemia $(p=0,968)$. Simpulan, efek samping terbanyak adalah gangguan gastrointestinal. [MKB. 2014;46(4):189-97]
\end{abstract}

Kata kunci: Efek samping, gangguan gastrointestinal, MDR TB, pendengaran, renal

\section{Multidrug Resistant Tuberculosis (MDR-TB): Epidemiologic Review and Adverse Events Risk Factors of Anti Tuberculosis Drugs}

\begin{abstract}
The number of Multi drug resistant tuberculosis (MDR-TB) cases is predicted to be increasing. The management of MDR-TB is more complex than susceptible TB due to the resistance to the first and second lines of anti tuberculosis drugs. Leading to anti tuberculosis drugs tolerance and adverse event issues. This study was a cohort study conducted between January 2011 and June 2013 to describe the type, frequency, and risk factors of adverse events caused by drugs. Sputum samples of patients who were suspected to have MDR TB were collected and examined as sputum smears using Ziehl Nielsen staining and Gene Xpert MTB/RIF segment amplification of rpoB gene region methods to assess resistance towards rifampicin. Samples with positive results were cultured in solid medium (Lowenstein Jensen) and liquid medium (Mycobacteria growth indicator tube test,MGIT). This study was conducted in Moewardi General Hospital. The number of confirmed MDR-TB patients was114 subject consisting of 56 males and 58 females. The most common adverse events were gastrointestinal disturbances including nausea $79.8 \%$ and vomiting $78.9 \%$. Minor adverse events also found in $76.3 \%$ patients. There was a significant relationship between previous anti tuberculosis medication and renal impairment $(\mathrm{p}=0.026)$; between sex and renal impairment $(p=0.033)$; and between sex and hearing impairment $(p=0.039)$. There was no significant relationship between sex and mental illnesses $(\mathrm{p}=0.062)$ as well as between previous anti tuberculosis medication and hearing impairment $(p=0.115)$ and between previous anti tuberculosis medication and hypopotassemia $(p=0.968)$. In conclusion, the major adverse events in MDR-TB cases are gastrointestinal disturbances. [MKB. 2014;46(4):189-97]
\end{abstract}

Key words: Adverse events, gastrointestinal disturbance, hearing impairment, MDR-TB, renal impairment

Korespondensi: Dr. Reviono, dr., Sp.P(K), Bagian Pulmonologi dan Ilmu Kedokteran Respirasi Fakultas Kedokteran Universitas Sebelas Maret Surakarta/Rumah Sakit Dr. Moewardi Jalan Kol. Soetarto 132 Surakarta, mobile 0818474671, e-mail reviono_05@yahoo.com 


\section{Pendahuluan}

Tuberkulosis (TB) sampai sekarang ini masih menjadi persoalan yang global, World Health Organization tahun 2011 menyatakan penyakit ini setiap tahunnya menginfeksi sekitar 9.000 .000 orang dan membunuh hampir 1.400 .000 orang di seluruh dunia. ${ }^{1}$ Di wilayah Asia Timur dan juga Selatan merupakan penyumbang kasus terbesar yaitu $40 \%$ atau 3.500 .000 kasus setiap tahunnya, dengan angka kematian yang cukup tinggi yaitu 26 orang per 100.000 penduduk. $^{2}$ Secara global diperkirakan terdapat 630.000 kasus multidrug resistant tuberculosis (MDR-TB). Kasus MDR TB dari tahun ke tahun diperkirakan akan terus meningkat. Selama tahun 2011 kasus MDR TB di Indonesia dilaporkan bahwa sejumlah 260 kasus, diperkirakan pada tahun 2013 akan terdeteksi 1.800 kasus. World Health Organization (WHO) pada tahun 2010, melaporkan untuk kasus MDRTB Indonesia berada di urutan ke-8. ${ }^{1}$ Multidrug resistant tuberculosis (MDR-TB) adalah kasus tuberkulosis yang disebabkan oleh Mycobacterium tuberculosis resisten minimal terhadap rifampisin dan isoniazid secara bersamaan, dengan atau tanpa obat antituberkulosis (OAT) lini I yang lain. ${ }^{3}$

Penatalaksanaan klinis MDR TB lebih rumit bila dibandingkan dengan TB yang sensitif karena mempergunakan obat anti-TB (OAT) lini I dan lini II. Pada tatalaksana TB yang sensitif hanya menggunakan 4 obat dan membutuhkan waktu 6 bulan, sedangkan pada tatalaksana MDR TB mempergunakan minimal 5 obat dan berlangsung selama 18 sampai 24 bulan. Tatalaksana kasus MDR TB ini sering dihubungkan dengan kejadian efek samping mulai dari yang ringan sampai yang berat. ${ }^{4}$ Cara yang rasional untuk memilih obat anti-TB secara tepat adalah menggunakan obat dari yang paling kuat efek bakterisidnya dengan toksisitas paling rendah sampai yang paling lemah dengan toksisitas paling tinggi. Pemilihan obat untuk kasus MDR TB antara lain menggunakan obat lini I jika masih efektif, satu obat injeksi, mempergunakan obat golongan flurokuinolon, menggunakan obat untuk kelompok 4 (lini II oral) sampai diperoleh empat jenis obat yang efektif, dan obat kelompok 5 untuk memperkuat regimen atau saat sebelum diperoleh empat jenis obat yang efektif dari kelompok sebelumnya. ${ }^{5}$ Terapi MDRTB menggunakan beberapa jenis obat sehingga menyebabkan beberapa permasalahan dalam hal toleransi terhadap obat-obatan tersebut. Respons masing-masing individu tidak dapat diprediksi, tetapi pengobatan tidak boleh dihentikan hanya karena ketakutan terhadap reaksi yang timbul. ${ }^{6}$

Penelitian ini bertujuan untuk menggambarkan macam dan juga frekuensi efek samping yang berhubungan penggunaan OAT pada kasus MDR TB dan untuk mengetahui hubungan faktor risiko dengan kejadian efek samping pada kasus MDR TB di rumah sakit.

\section{Metode}

Penelitian ini dilaksanakan di poli Programmatic Management of Drug Resistant Tuberculosis (PMDT) RSUD Dr. Moewardi Surakarta yang merupakan pusat rujukan pasien MDR-TB di Jawa Tengah. Penelitian ini merupakan penelitian kohort antara Januari 2011 sampai Juni 2013. Kriteria inklusi adalah pasien usia $>20$ tahun dan terkonfirmasi sebagai pasien MDR TB. Kriteria eksklusi apabila data penelitian tidak lengkap.

Subjek penelitian adalah pasien MDR TB yang datang ke poli PMDT. Semua suspek MDR TB (terdapat 9 kriteria) diambil sputum sewaktu, pagi, sewaktu untuk dilakukan pengecatan Ziehl Nielsen. Apabila hasilnya menunjukkan positif basil tahan asam (BTA) lalu dilanjutkan dengan pemeriksaan Xpert assay atau Xpert MTB/ RIF yaitu amplifikasi segmen Mycobacterium tuberculosis regio gen rроB untuk menentukan resistensi terhadap rifampisin. Hasil pemeriksaan Xpert MTB/RIF positif dilanjutkan pemeriksaan uji resistensi terhadap obat-obat anti-TB dengan media padat (Lowenstein Jensen) dan juga biakan cair Mycobacteria growth indicator tube test (MGIT) di Laboratorium Mikrobiologi Fakultas Kedokteran Universitas Indonesia Jakarta.

Pasien yang dikonfirmasi sebagai pasien MDR TB diberikan informasi tentang terapi MDR-TB. Tim ahli klinis (TAK) akan memeriksa pasien kemudian dilakukan pemeriksaan darah lengkap, kreatinin serum, asam urat, pemeriksaan fungsi hepar (transaminase serum, bilirubin serum, dan alkali fosfatase), TSH, HBsAg, foto toraks, pemeriksaan psikiatri, EKG, konsultasi VCT, dan pemeriksaan audiometri sebelum memulai terapi. Foto toraks dilakukan setiap enam bulan dan audiometri dilakukan setiap bulan selama fase awal. Untuk tahap lanjutan pemeriksaan audiometri dilakukan 2 bulan sekali. Pemeriksaan fungsi tiroid dan juga elektrolit dilakukan sesuai dengan klinis pasien atas persetujuan TAK. Tim dokter serta perawat yang sudah dilatih untuk penanganan MDR TB akan mengikuti perjalanan penyakit pasien selama dan juga setelah rawat inap di rumah sakit. Tim dokter akan menanyakan efek samping yang mungkin akan dialami oleh pasien. Gejala yang berhubungan dengan efek samping dicatat pada formulir follow-up pasien. Untuk penanganan efek samping tersebut, terapi diberikan sesuai dengan persetujuan TAK bersama ke tim terapeutik. Catatan medis diperiksa untuk 
memperoleh data mengenai usia, jenis kelamin, komorbid, regimen standar yang diterima pasien, efek samping, dan obat yang dihentikan karena efek samping.

Pasien mulai diberikan rejimen sesuai standar terdiri atas 5 atau 6 jenis obat. Obat dan dosis yang digunakan pada rejimen terapi dipaparkan pada Tabel 1. Obat anti-TB yang diberikan kanamisin $(\mathrm{Km})$, levofloxacin (Lfx), etionamid (Eto), etambutol (E) jika masih sensitif, pirazinamid (Z), cycloserin (Cs), diberikan juga vitamin B. Injeksi diberikan selama 5 hari (Senin-Jumat) dan terapi oral diberikan setiap hari (Senin-Minggu). Etika penelitian didapatkan dari Komite Etik Fakultas Kedokteran Universitas Sebelas Maret (FKUNS). Setiap efek samping yang tidak diinginkan yang ditemukan pada saat pengumpulan data langsung dilaporkan pada dokter penanggung jawab pasien untuk ditatalaksana.

Semua data yang telah terkumpul lalu dianalisis mempergunakan statistical product and service solutions atau SPSS for windows versi 21.00. Hubungan antara efek samping terapi MDR TB dan faktor risiko dianalisis menggunakan uji chikuadrat dengan nilai signifikansi $\mathrm{p}<0,05$.

\section{Hasil}

Jumlah pasien yang terkonfirmasi MDR TB adalah sebanyak 114 orang yang terdiri atas 56 orang laki-laki dan 58 perempuan. Usia $>41$ tahun lebih banyak dibandingkan dengan usia 20-40 tahun. Pasien dengan komorbid diabetes melitus (DM) sebanyak 24 orang. Pasien dengan riwayat pengobatan TB kategori 2 berjumlah 103 orang. Karakteristik pasien MDR TB yang mendapat terapi MDR TB di poli PMDT RS Dr. Moewardi Surakarta Januari 2011-Juni 2013 tampak pada Tabel 2.
Efek samping yang terjadi antara lain berupa mual dan muntah, artralgia, gangguan psikiatri, renal, gangguan pendengaran, gangguan tidur, hipokalemia, hiperurisemia, diare, nyeri pada tempat suntikan, derajat efek samping (berat dan ringan). Efek samping yang paling banyak terjadi adalah mual yang terjadi pada $91(79,8 \%)$ pasien, muntah dan artralgia yang terjadi pada $90(78,9 \%)$ pasien. Efek samping yang jarang terjadi adalah hipokalemia $20(17,5 \%)$ pasien. Distribusi efek samping terapi MDR TB tampak pada Tabel 3.

Derajat efek samping berat lebih banyak pada usia $>41$ tahun dibandingkan dengan usia 20-40 tahun walaupun secara statistik jumlahnya tidak bermakna. Laki-laki dan perempuan mengalami derajat efek samping yang berat ternyata hampir sama. Pasien dengan komorbid non-DM lebih banyak mengalami derajat efek samping berat dibandingkan dengan pasien MDR TB dengan komorbid DM meskipun jumlahnya secara stastik tidak bermakna. Hubungan derajat efek samping dengan usia, jenis kelamin, komorbid, dan riwayat pengobatan tampak pada Tabel 4. Pasien dengan riwayat pengobatan kategori 2 yang mengalami gangguan renal 58 pasien, gangguan pendengaran 59 pasien, dan hipokalemia 19 pasien.

Terdapat hubungan signifikan antara pasien riwayat pengobatan kategori 2 serta gangguan renal bila dibandingkan pasien dengan riwayat pengobatan kategori 1 dengan $p<0,026$. Hubungan riwayat pengobatan TB dengan hipokalemia, gangguan pendengaran, dan juga renal pasien MDR TB tampak pada Tabel 5.

Pasien laki-laki lebih banyak mengalami gangguan renal apabila dibandingkan dengan perempuan. Hubungan antara laki-laki dengan gangguan renal signifikan $(p=0,033)$. Hubungan jenis kelamin dengan gangguan pendengaran yang signifikan $(p=0,039)$, perempuan lebih banyak mengalami gangguan pendengaran dibandingkan

Tabel 1 Penentuan Dosis OAT MDR-TB berdasarkan Kelompok Berat Badan Pasien

\begin{tabular}{|c|c|c|c|c|}
\hline \multirow{2}{*}{ OAT } & \multicolumn{4}{|c|}{ Berat Badan (BB) } \\
\hline & $<33 \mathrm{~kg}$ & $33-50 \mathrm{~kg}$ & $51-70 \mathrm{~kg}$ & $>70 \mathrm{~kg}$ \\
\hline Pirazinamid (Z) & $20-30 \mathrm{mg} / \mathrm{kg} / \mathrm{hari}$ & $750-1.500 \mathrm{mg}$ & $1.500-1.750 \mathrm{mg}$ & $1.750-2.000 \mathrm{mg}$ \\
\hline $\operatorname{Kanamisin}(\mathrm{Km})$ & $15-20 \mathrm{mg} / \mathrm{kg} / \mathrm{hari}$ & $500-750 \mathrm{mg}$ & $1.000 \mathrm{mg}$ & $1000 \mathrm{mg}$ \\
\hline Etambutol (E) & $20-30 \mathrm{mg} / \mathrm{kg} / \mathrm{hari}$ & $800-1.200 \mathrm{mg}$ & $1.200-1.600 \mathrm{mg}$ & $1.600-2.000 \mathrm{mg}$ \\
\hline Capreomycin $(\mathrm{Cm})$ & $15-20 \mathrm{mg} / \mathrm{kg} / \mathrm{hari}$ & $500-750 \mathrm{mg}$ & $1.000 \mathrm{mg}$ & $1.000 \mathrm{mg}$ \\
\hline Levofloksasin (Lfx) & $7,5-10 \mathrm{mg} / \mathrm{kg} / \mathrm{hari}$ & $750 \mathrm{mg}$ & $750 \mathrm{mg}$ & $750-1.000 \mathrm{mg}$ \\
\hline Moksifloksasin (Mfx) & $7,5-10 \mathrm{mg} / \mathrm{kg} / \mathrm{hari}$ & $400 \mathrm{mg}$ & $400 \mathrm{mg}$ & $400 \mathrm{mg}$ \\
\hline Cycloserin (Cs) & $15-20 \mathrm{mg} / \mathrm{kg} / \mathrm{hari}$ & $500 \mathrm{mg}$ & $750 \mathrm{mg}$ & $750-1.000 \mathrm{mg}$ \\
\hline Etionamid (Eto) & $15-20 \mathrm{mg} / \mathrm{kg} / \mathrm{hari}$ & $500 \mathrm{mg}$ & $750 \mathrm{mg}$ & $750-1.000 \mathrm{mg}$ \\
\hline PAS & $150 \mathrm{mg} / \mathrm{kg} / \mathrm{hari}$ & $8 \mathrm{~g}$ & $8 \mathrm{~g}$ & $8 \mathrm{~g}$ \\
\hline
\end{tabular}


Tabel 2 Karakteristik Pasien MDR TB di Poli PMDT RS Dr. Moewardi Januari 2011-Juni 2013

\begin{tabular}{lcc}
\hline Karakteristik & $\begin{array}{c}\text { Jumlah } \\
(\mathbf{n}=\mathbf{1 1 4})\end{array}$ & $\begin{array}{c}\text { Presentase } \\
\mathbf{( \% )}\end{array}$ \\
\hline Jenis kelamin & & \\
$\quad$ Laki-laki & 56 & 46,5 \\
$\quad$ Perempuan & 58 & 50,9 \\
Usia (tahun) & & \\
20-40 & 53 & 46,5 \\
41 & 61 & 53,5 \\
Komorbid & & \\
$\quad$ DM & 24 & 21,1 \\
$\quad$ Non DM & 90 & 78,9 \\
Riwayat pengobatan & & \\
Kategori 1 & 11 & 9,6 \\
$\quad$ Kategori 2 & 103 & 90,4 \\
Derajat efek samping & & \\
$\quad$ Berat & 27 & 23,7 \\
$\quad$ Ringan & 87 & 76,3 \\
\hline
\end{tabular}

dengan laki-laki. Hubungan jenis kelamin dengan gangguan renal, gangguan pendengaran, dan juga gangguan psikiatri pasien MDR TB di poli PMDT RS Dr. Moewardi Surakarta Januari 2011-Juni 2013 dapat dilihat pada Tabel 6.
Tabel 3 Efek Samping Terapi MDR TB di Poli PMDT RS Dr. Moewardi Surakarta Januari 2011-Juni 2013

\begin{tabular}{lcc}
\hline \multicolumn{1}{c}{ Efek Samping } & $\begin{array}{c}\text { Jumlah } \\
(\mathbf{n = 1 1 4})\end{array}$ & $\begin{array}{c}\text { Presentase } \\
\mathbf{( \% )}\end{array}$ \\
\hline Mual & 91 & 79,8 \\
Muntah & 90 & 78,9 \\
Artralgia & 90 & 78,9 \\
Gangguan renal & 68 & 59,6 \\
Gangguan & & 59,6 \\
pendengaran & 68 & 53,5 \\
Gangguan psikiatri & 61 & 52,6 \\
Hipokalemia & 60 & 49,1 \\
Diare & 56 & 37,7 \\
Hiperurisemia & 43 & 21,9 \\
Nyeri tempat & 25 & 18,4 \\
suntikan & 21 & \\
Gangguan tidur &
\end{tabular}

\section{Pembahasan}

Mual dan muntah (gangguan gastrointestinal) merupakan efek samping yang paling sering ditemukan dibandingkan dengan efek samping lainnya yaitu $79,8 \%$ dan $78,9 \%$. Pada penelitian ini tidak dapat menunjukkan obat yang diduga sebagai penyebabnya efek samping tersebut.

Tabel 4 Hubungan Derajat Efek Samping dengan Usia, Jenis Kelamin, Komorbid, dan Riwayat Pengobatan pada Pasien MDR TB di Poli PMDT RS Dr. Moewardi Januari 2011-Juni 2013

\begin{tabular}{lccc}
\hline \multirow{2}{*}{ Karakteristik } & \multicolumn{2}{c}{ Derajat Efek Samping $(\mathbf{n}=\mathbf{1 1 4})$} & \multirow{2}{*}{$\mathbf{p}^{*}$} \\
\cline { 2 - 4 } & Berat $\mathbf{n}=\mathbf{2 7}$ & Ringan $\mathbf{n}=\mathbf{8 7}$ & 0,117 \\
\hline Usia (tahun) & 9 & 44 & \\
$20-40$ & 18 & 43 & 0,908 \\
$>41$ & & & \\
Jenis kelamin & 13 & 43 & 0,865 \\
$\quad$ Laki-laki & 14 & 44 & \\
Perempuan & & & \\
Komorbid & 6 & 18 & 0,298 \\
DM & 21 & 69 & \\
Non DM & 4 & & \\
Riwayat pengobatan & 23 & 7 & \\
Kategori 1 & & 80 & \\
Kategori 2 & & & \\
\hline
\end{tabular}

Keterangan: *uji chi-kuadrat 
Tabel 5 Hubungan Riwayat Pengobatan TB dengan Hipokalemia, Gangguan Pendengaran, dan Gangguan Renal Pasien MDR TB di Poli PMDT RS Dr. Moewardi Januari 2011-Juni 2013

\begin{tabular}{lccc}
\hline \multirow{2}{*}{ Efek Samping } & \multicolumn{2}{c}{ Riwayat Pengobatan (n=114) } & . \\
\cline { 2 - 3 } & $\begin{array}{c}\text { Kategori 1 } \\
\mathbf{n = 1 1}\end{array}$ & $\begin{array}{c}\text { Kategori 2 } \\
\mathbf{n = 1 0 3}\end{array}$ & \\
\hline Hipokalemia & 7 & 53 & 0,968 \\
Gangguan pendengaran & 9 & 59 & 0,115 \\
Gangguan renal & 10 & 58 & 0,026 \\
\hline
\end{tabular}

Keterangan: *uji chi-kuadrat

Beberapa obat yang diduga sebagai penyebab timbulnya efek samping mual dan muntah adalah Eto, PAS, serta Z. Mual dan muntah merupakan keluhan tersering pada kasus MDR TB juga ditemukan pada penelitian Shin dkk. ${ }^{7}(75,4 \%)$, Bloss dkk. ${ }^{4}$ (58\% dan 39\%), Nathanson dkk. ${ }^{8}$ $(32,8 \%)$, dan Sagwa dkk. ${ }^{9}$ (23\%). Efek samping keluhan mual dan muntah ini yang paling sering menyebabkan penambahan obat-obat simtomatis tanpa harus mengubah regimen terapi sebelumnya. Efek samping terapi MDR-TB pada gangguan gastrointestinal pada penelitian ini diberikan obat simtomatis antara lain ranitidin, omeprazol, sukralfat, ondansentron, atau metoklorperamid berdasarkan respons klinis.

Efek samping gangguan renal pada penelitian terdapat $59,6 \%$, temuan serupa dilaporkan oleh Shin dkk. ${ }^{7}(9,8 \%)$. Penelitian Nathason dkk. ${ }^{8}$ juga menemukan $1,1 \%$ pasien dengan gagal ginjal/ nefrotoksik pada pemberian terapi MDR TB. Pada penelitian ini pasien dengan riwayat pengobatan TB dengan menggunakan kategori 2 mempunyai hubungan yang signifikan dengan gangguan renal $(p=0,026)$. Keadaan ini kemungkinan disebabkan karena penggunaan obat golongan aminoglikosida dalam waktu yang lama. Aminoglikosida bersifat nefrotoksik karena menginduksi nekrosis tubulus proksimal mulai dari lesi fokal sampai difus. Aminoglikosida itu sebagian besar diekskresi melalui filtrasi oleh glomerulus. Ambang klinis nefrotoksisitas aminoglikosida ditentukan oleh kecepatan nekrosis dan kecepatan regenerasi sel tubulus proksimal. ${ }^{10}$ Penelitian yang dilakukan oleh de Joger dan Van Althena ${ }^{11}$ menunjukkan terdapat hubungan yang bermakna nefrotoksisitas dengan lama pengobatan serta pemberian total dosis aminoglikosida tersebut. ${ }^{11}$ Pada penelitian ini juga ditemukan laki-laki lebih sering terjadi gangguan renal daripada perempuan $(p=0,033)$. Penelitian oleh Sturdy dkk. ${ }^{12}$ menyatakan tidak ada perbedaan nefrotoksik antara laki-laki dan perempuan $(p=0,944)$. Perbedaan ini masih perlu diteliti lebih lanjut kemungkinan terdapat faktor genetik yang ikut berperan. Pada penelitian lain, Bloss dkk. ${ }^{4}$ menyampaikan hal yang berbeda yaitu secara umum pada perempuan dan orang tua cenderung lebih banyak menderita efek samping pada kasus MDR TB.

Tatalaksana efek samping gangguan renal pada penelitian ini diberikan edukasi minum air putih yang cukup kepada pasien serta keluarga pasien. Bila gangguan renal tetap berlanjut maka dilakukan subsitusi dengan obat yang sekelompok. Telah dilaporkan beberapa kasus efek samping berat pada gangguan renal, sehingga pemberian kanamisin dihentikan dan diganti capreomycin dengan pemberian seminggu 3 kali.

Gangguan pendengaran juga cukup banyak ditemukan sebanyak 59,6\%. Hasil serupa juga dilaporkan oleh Singh dkk. ${ }^{7}$ kejadian ototoksik

Tabel 6 Hubungan Jenis Kelamin dengan Gangguan Renal, Gangguan Pendengaran, dan Gangguan Psikiatri Pasien MDR TB di Poli PMDT RS Dr. Moewardi Surakarta Januari 2011-Juni 2013

\begin{tabular}{lccc}
\hline \multirow{2}{*}{ Efek Samping } & \multicolumn{2}{c}{ Jenis Kelamin $(\mathbf{n = 1 1 4})$} & \multirow{2}{*}{$\mathbf{p}^{*}$} \\
\cline { 2 - 4 } & $\begin{array}{c}\text { Laki-laki } \\
\mathbf{n = 5 6}\end{array}$ & $\begin{array}{c}\text { Perempuan } \\
\mathbf{n = 5 8}\end{array}$ & 0,033 \\
\hline Gangguan renal & 39 & 29 & 0,039 \\
Gangguan pendengaran & 28 & 40 & 0,062 \\
Gangguan psikiatri & 25 & 36 & 0 \\
\hline
\end{tabular}

Keterangan: *uji chi-kuadrat 
pada $15,6 \%$ pasien. Penelitian oleh Ramma dan Ibekwe $^{13}$ menunjukkan gangguan pendengaran terjadi sebanyak $25 \%$ pasien. Guideline WHO merekomendasikan injeksi lini II (amikasin, kanamisin, dan capreomycin) untuk MDR TB. Masalah penting yang erat hubungannya dengan pemberian obat injeksi jangka panjang adalah toksisitas. Ototoksisitas dan juga nefrotoksisitas sudah banyak dilaporkan sebagai efek samping aminoglikosida yang berhubungan dengan besar dosis. Paparan awal obat ototoksik ini biasanya memengaruhi daerah koklea yang mengatur kode jumlah tinggi. Paparan berkesinambungan akan menyebabkan penyebaran kerusakan ke jumlah yang lebih rendah secara progresif. ${ }^{8}$ Ototoksitas mempunyai sifat yang permanen. Faktor risiko terjadinya ototoksistas yaitu akumulasi obat, lama terapi, bakteremia, gangguan ginjal atau hepar, dan juga penggunaan obat MDR TB dengan diuretik yang mempunyai efek otoktositas yang sinergik. Penelitian Harris dkk. ${ }^{14}$ mendapatkan perempuan lebih banyak mengalami ototoksisitas dibandingkan dengan laki-laki, tetapi tidak ada hubungan yang signifikan antara jenis kelamin dan terapi MDR TB. Mekanisme ototoksisitas aminoglikosida itu diperantarai oleh gangguan sintesis protein mitokondria dan formasi radikal bebas yang diikuti destruksi sel rambut koklea terutama pada lapisan luar. ${ }^{10}$ Penelitian ini juga menemukan perempuan lebih sering mengalami gangguan pendengaran $(\mathrm{p}=0,039)$. Hasil yang berbeda dilaporkan oleh Sturdy dkk. ${ }^{12}$ yaitu tidak ada perbedaan hearing loss antara laki-laki dan perempuan $(p=0,477)$. Efek samping gangguan pendengaran yang terjadi pada penelitian ini diberikan neurotropik dan evaluasi penggunaan kanamisin. Injeksi kanamisin untuk sementara dihentikan terhadap seorang pasien karena terjadi gangguan pendengaran.

Kejadian hipokalemia pada penelitian ini yaitu didapatkan pada $52,6 \%$ pasien. Pada penelitian ini tidak didapatkan hubungan yang signifikan antara jenis kelamin dan hipokalemia $(p=0,093)$. Penelitian Hesling mencurigai terdapat gangguan elektrolit pada $14,7 \%$ pasien yang mendapatkan capreomycin. ${ }^{15}$ Nathanson dkk. ${ }^{8}$ telah menemukan $11,5 \%$ pasien mengalami gangguan elektrolit. Gangguan elektrolit tersebut merupakan salah satu efek samping yang paling menantang pada penanganan MDR TB, terutama oleh karena tidak terdapat gejala yang menggambarkan kelainan ini serta potensi morbiditasnya yang berhubungan dengan kelainan ini. Alasan terjadinya gangguan elektrolit pada pasien yang menjalani terapi MDR TB kemungkinan bersifat multifaktorial.

Sejumlah penyakit yang kronik berhubungan dengan defisiensi kalium maupun magnesium seperti tuberkulosis, malnutrisi, alkoholisme, dan diabetes melitus. Selain itu, diare dan muntah akibat pemberian obat antituberkulosis juga dapat berperan terhadap terjadinya kehilangan elektrolit melalui saluran gastrointestinal. ${ }^{15}$ Hipokalemia lebih sering terjadi pada perempuan mungkin disebabkan berkurangnya massa otot dan tempat pertukaran $\mathrm{K}^{+}$yang kecil. ${ }^{16}$

Efek samping lain artralgia dan hiperurisemia yang terjadi pada terapi MDR TB, kemungkinan disebabkan oleh pemberian pirazinamid maupun levofloxacin. Pada kasus ini ditatalaksana dengan pemberian alopurinol, piroksikam meloksikam, atau tramadol. Pada beberapa pasien, dosis pirazinamid diturunkan dan dievaluasi tiga hari. Jika hasil pemeriksaan asam urat normal kembali maka diberikan dosis pirazinamid sesuai dengan dosis yang sudah ditentukan.

Gangguan psikiatri yaitu ansietas dan depresi pada penelitian ini cukup tinggi yaitu 53,5\%. Beberapa penelitian melaporkan awal pengobatan terjadi ansietas dan depresi yang cukup tinggi pada pasien MDR TB. Keadaan ini kemungkinan disebabkan oleh persepsi masyarakat terhadap penderita TB yang salah, antara lain adalah stigmatisasi. Bloss dkk. ${ }^{4}$ telah melaporkan terdapat $13 \%$ kasus MDR TB yang mengalami ansietas dan depresi. Munculnya gangguan psikiatri ini sangat berpengaruh terhadap keberhasilan pengobatan, karena pasien sulit untuk diajak kerjasama baik dalam pemberian obat maupun pemeriksaan lain yang harus dilakukan. Oleh karena itu, dalam penatalaksanaan MDR TB diperlukan kerjasama yang erat antara tim ahli klinis (TAK) dan ahli kesehatan mental.

Obat yang mungkin berhubungan dengan gangguan psikiatri yaitu terapi sikloserin. Pasien dengan gangguan psikiatri pada penelitian ini dikonsultasikan kepada bagian psikiatri, kemudian pasien diterapi dengan flusetin serta klobazam. Gangguan psikiatri yang berat pada penelitian ini sikloserin dihentikan dan dievaluasi. Jika kondisi sudah membaik sikloserin dapat diberikan lagi. Edukasi kepada pasien maupun keluarga juga dilakukan untuk mengendalikan efek samping yang terjadi.

Gangguan tidur terdapat 18,4\%, kemungkinan disebabkan karena levofloxacin. Pasien dengan gangguan tidur yang berat pada penelitian ini diberikan alprazolam. Pasien diedukasi untuk datang ke fasilitas layanan kesehatan pagi atau siang hari untuk minum obat. Nyeri pada tempat suntikan didapatkan $21,9 \%$, kemungkinan akibat pemberian obat kanamisin maupun capreomycin. Akibat efek samping ini pasien diedukasi untuk dikompres dan apabila mengganggu diberi obat meloksikam atau parasetamol.

Usia adalah faktor independen terkait MDR TB dan secara signifikan terjadi pada usia 45-65 
tahun. Pada penelitian ini MDR TB banyak terjadi pada usia $>41$ tahun. Faustini dkk. ${ }^{17}$ menemukan MDR TB terjadi pada usia kurang dari 65 tahun tetapi mempunyai hubungan yang lemah dan lebih heterogen pada pasien di bawah 45 tahun. Pasien TB usia muda secara bermakna menjadi MDR TB dibandingkan dengan usia tua. ${ }^{18}$

Di Texas serta Meksiko dilaporkan bahwa pasien DM tipe 2 lebih rentan terhadap terjadinya MDR TB. Pasien DM tipe 2 merupakan populasi terbesar kasus TB aktif di Meksiko dan Mexican Amerika. Populasi ini berkontribusi terhadap peningkatan kasus MDR TB. ${ }^{18}$ Diabetes melitus tipe 2 menyebabkan penurunan sistem imunitas tubuh, hal ini berhubungan dengan kontrol gula darah yang buruk. Kontrol gula darah yang buruk dapat menyebabkan gangguan fungsi fagositosis, kemotaksis, reactive oxygen species (ROS), dan fungsi sel $\mathrm{Th}_{17}{ }^{18}$

Prevalensi efek samping pada kasus MDR TB pada beberapa penelitian cukup bervariasi. Beberapa faktor yang diduga sebagai penyebab perbedaan prevalensi adalah definisi terminologi efek samping, apakah merupakan keluhan pasien (subjektif) atau sudah ditetapkan oleh penelitian (objektif) dengan kriteria tertentu sehingga tidak semua keluhan diteliti. Kemungkinan faktor lain adalah paduan obat anti-MDR TB yang bervariasi, juga terdapat perbedaan komorbid atau kondisi lain dari pasien yang tidak sama. ${ }^{9}$

Keterbatasan penelitian ini yaitu, pasien yang diteliti adalah pasien yang dirawat di rumah sakit. Pasien mempunyai kesempatan yang lebih luas untuk berinteraksi dengan dokter dibandingkan dengan pasien rawat jalan, sehingga lebih leluasa menyampaikan keluhannya. Tatalaksana kasus MDR TB pada masa-masa yang akan datang seperti pasien TB yang masih sensitif (non MDR) yaitu rawat jalan yang dipantau oleh puskesmas terdekat. Pada penelitian ini tidak dapat dilakukan generalisasi pada pasien rawat jalan.

Pada penelitian ini juga tidak diperhitungkan pengaruh genetik: faktor genetik Mycobacterium tuberculosis maupun faktor genetik pasien yang kemungkinan akan memengaruhi perjalanan klinis pasien termasuk efek samping. Untuk faktor genetik Mycobacterium tuberculosis, Soetikno dan Parwati ${ }^{19}$ melaporkan bahwa Mycobacterium tuberculosis genotip Beijing mempunyai virulensi lebih tinggi dan lebih resisten bila dibandingkan dengan genotip non-Beijing. Untuk faktor genetik pada pasien, Setiabudiawan dkk. ${ }^{20}$ melaporkan polimorfisme FokI gen reseptor vitamin D (RVD) berhubungan dengan kejadian TB.

Simpulan, efek samping terbanyak pada kasus MDR TB adalah mual dan muntah, serta artralgia. Sebagian besar efek samping itu adalah derajat ringan dan dapat diatasi dengan memberikan obat simtomatis tanpa mengubah paduan obat. Efek samping gangguan renal berhubungan dengan riwayat pengobatan TB sebelumnya dan lebih banyak terjadi pada laki-laki. Sebaliknya, untuk gangguan pendengaran lebih banyak terjadi pada perempuan. Efek samping dari gangguan psikiatri cukup banyak sehingga perlu kerjasama yang erat antara tim ahli klinis dan ahli kesehatan jiwa.

\section{Daftar Pustaka}

1. World Health Organization. Global tuberculosis control. WHO report 2012. Geneva: WHO; 2102.

2. World Health Organization. Tuberculosis control in the South-East Asia Region: Anual report 2013. New Delhi: WHO Library Cataloguing-in-Publication data; 2013.

3. World Health Organization. Multidrug and extensively drug-resistant TB (M/XDRTB): 2010 global report on surveillance and response. WHO Library Cataloguing-inPublication Data. WHO/HTM/TB/2010.3. p.ix.

4. Bloss E, Kukša L, Holtz TH, Riekstina V, Skripc onoka V, Kammerer S, dkk. Adverse events related to multidrug-resistant tuberculosis treatment, Latvia, 2000-2004. Int J Tuberc Lung Dis. 2010;14(3):275-81.

5. Mondero I, Caminero JA. Management of multidrug resistant tuberculosis an update. Ther Adv Respir Dis. 2010;4(2):117-27.

6. Fattiyah I, Zubaedah T, Priyanti ZS, Erlina $\mathrm{B}$, Reviono, Soedarsono, dkk, penyunting. Tuberkulosis pedoman diagnosis dan penatalaksanaan di Indonesia. Edisi revisi pertama. Jakarta: PDPI; 2011.

7. Shin SS, Pasechnikov AD, Gelmanova IY, Peremitin GG, Strelis AK, Mishustin S, dkk. Adverse reactions among patients being treated for MDR-TB in Tomsk, Russia. Int J Tuberc Lung Dis. 2007;11(12):1314-20.

8. Nathanson E, Gupta R, Huamani P, Leimane V, Pasechnikov AD, Tupasi TE, dkk. Adverse events in the treatment of multidrug-resistant tuberculosis: results from the DOTSPlus initiative. Int $\mathrm{J}$ Tuberc Lung Dis. 2004;8(11):1382-4.

9. Sagwa E, Kaija A, Teeuwisse M, Ruswa N, Musasa JP, Pal S, dkk. The burden of adverse events during treatment of drug-resistant tuberculosis in Namibia Southern. Med Rev. 2012;5(1):6-13.

10. Huth ME, Ricci AJ, Cheng AG. Mechanisms of aminoglycoside ototoxicity and targets of hair cell protection. Int $\mathrm{J}$ Otolaryngol. 2011;2011:937861. 
11. De Jager P, van Altena R. Hearing loss and nephrotoxicity in long-term aminoglycoside treatment in patients with tuberculosis. Int $\mathrm{J}$ Tuberc Lung Dis. 2002;6(7):622-7.

12. Sturdy A, Goodman A, Jose'RJ, Loyse A, O'Donoghue M, Kon OM, dkk. Multidrugresistant tuberculosis (MDR-TB) treatment in the UK: a study of injectable use and toxicity in practice. J Antimicrob Chemother. 2011;66:1815-20.

13. Ramma L, Ibekwe TS. Cochleo-vestibular clinical findings among drug resistant tuberculosis patient on therapy-a pilot study. Int Arc Med. 2012;5:3.

14. Harris T, Bardien S, Schaaf HS, Petersen L, De Jong G, Fagan JF. Aminoglycoside induced hearing loss in HIV positive and HIV negative multidrug resistant tuberculosis patients. S Afr Med J. 2012;102(6):363-6.

15. Shingh S, Furin J, Hyson A, Joseph K, Rich M, Alcantra F, dkk. Hypokalemia among patients receiving treatment for multidrug- resistant tuberculosis. Chest. 2004;125:97480.

16. Unwin JR, Luft FC, Shierly DG. Pathophysiology and management of hypokalemia: clinical persepective. Nature Rev Nephrol. 2011;7:75-84.

17. Faustini A, Hall AJ, Perucci CA. Risk factor for multidrug resistant tuberculosis in Europe: a systemic review. Thorax. 2006;(61):58-63.

18. Fisher-Hoch SP, Whitney E, McCormick JB, Crespo G, Smith B, Restrepo B, dkk. Type 2 diabetes and multi-drug resistant tuberculosis. Scan J Infected Dis. 2008;4(11-12):888-93.

19. Soetikno RD, Parwati I. Gambaran foto toraks tuberkulosis paru genotipe Beijing dan Non-Beijing. MKB. 2010;42(3):92-5.

20. Setiabudiawan B, Kartasasmita CB, Garna H, Parwati I, Maskoen AM. Polimorfisme fokI, bsmI, apaI, dan taq $\mathrm{I}$ gen reseptor vitamin D pada kejadian tuberkulosis anak. MKB. 2010;42(4):187-94. 